В. А. Лозового, Н. Г. Чибисовой, А. В. Шило. - Сумы: Университет, 1999. - 304 с.

УДК 373.5.016:91

Свімлана Тросюк

\title{
РОЗРОБЛЕННЯ КРАЇНОЗНАВЧОГО СКЛАДНИКА У ЗМІСТІ ПРЕДМЕТНОЇ КОМПЕТЕНТНОСТІ УЧНІВ ОСНОВНОЇ ШКОЛИ
}

Тросюк С. Д. Розроблення країнознавчого складника у змісті предметної компетентності учнів основної школи.

У статті розкрито алгоритм формування країнознавчих понять у змісті предметної компетентності учнів основної школи. Наведено приклади роботи 3 географічними i країнознавчими поняттями на рівні зіставлення i системних взаємозв'язків. Країнознавчий складник розглядається як фоновий у процесі формування географічної компетентності учнів основної школи під час вивчення географії України.

Ключові слова:учні основної школи, предмети природничого циклу, країнознавчий складник, географічна компетентність, географічні поняття, країнознавчі поняття.

Тросюк С. Д. Разработка страноведческого компонента в содержании предметной компетентности учащихся основной школы.

В статье раскрыт алгоритм формирования страноведческих понятий в содержании предметной компетентности учащихся основной школы. Приведены примеры работы с географическими и страноведческими понятиями на уровне сопоставления и системных взаимосвязей. Страноведческая составляющая рассматривается как фоновая при формировании географической компетентности учащихся основной школы в процессе изучения географии Украины.

Ключевые слова: учащиеся основной школы, предметы естественного цикла, страноведческая составляющая, географическая компетентность, географические понятия, страноведческие понятия.

Trosyuk S. D. Development of regional studies component in the content of geographical competence of primary school pupils.

This article deals with an algorithm of forming geographic concepts in the sense of geographical competence of primary school pupils. Providesexamples of the geographic and regional concept level matching and system interconnections. Geographic component is considered as a background in the formation of geographical competence of primary school students in the study of the geography of Ukraine.

Keywords: primary school pupils, subjects of natural sciences, geographic component, geographical expertise, geographic concepts, geographic concepts.

Новітня концепція освіти визначає складником державних освітніх стандартів компетентність того, хто оволодіває освітою. За основну мету середньої школи ставиться виховання й навчання людини, здатної до культурного творіння й продуктивного діалогу 3 соціумом, яка володіє необхідними для здійснення навчальної і практичної діяльності знаннями, уміннями і навичками, тобто успішного розв'язання предметних завдань, що дає змогу бути обізнаним у справах певної галузі, кваліфіковано розв'язувати питання сфери діяльності.

Основні складники методики формування предметної компетенції, пов'язані 3 уведенням їх, складанням визначень і розкриттям суттєвих та несуттєвих ознак, а також іiі розвитком під час практичного застосування, виявлено у дослідженнях вітчизняних і зарубіжних педагогів, зокрема: Ю. Бабанського, І. Беха, С. Гончаренка, Г. Ковальчук, В. Кременя, В. Краєвського, О. Пометун, М. Поташника, Н. Тализіної, 174

Педагогіка вищої та середної школи. - 2014. - Вип. 41 
дидактів -В. Беспалька, Л. Занкова, В. Паламарчук, П. Підкасистого, М. Скаткіна, Г. Усової; географів та методистів-географів - Є. Алаєва, М. Баранського, Н. Бірюкової, О. Бугрій, Л. Вішнікіної, В. Корнєєва, Л. Круглик, Т. Назаренко, В.Самойленка, А. Сиротенка, М. Топузова, О. Топузова, Г. Уварової, Б. Чернова та інших.

Незважаючи на значущість отриманих науковцями результатів, остаточно не визначено концептуальну й організаційно-педагогічну основу навчання, зорієнтованого на оволодіння компетенціями й компетентностями, а також зміст і структуру країнознавчого складника предметної компетентності учнів основної школи; не знайшли висвітлення соціокультурні чинники ефективного її формування. Тому констатуємо, що донині не розроблено ефективної дидактичної системи формування країнознавчого складника предметної компетентності учнів основної школи у процесі навчання географії України.

Mema cmammi-розкрити алгоритм формування країнознавчих понять у змісті географічної компетентності учнів основної школи.

Ми розуміємо країнознавчу компетенцію в учнів під час вивчення географії як фонову, яка перебуває в системних взаємозв'язках із географічною й культурологічною компетенціями.

Географічна компетенція становить знання учнів про історію,географію, економіку, державний устрій країни, що вивчається. Сформованість географічної компетенції засвідчує високий рівень географічної культури учнів основної школи, що виявляється на рівні географічного бачення світу; у географічному мисленні; умінні застосовувати географічні методи і мову (поняття, терміни, карту).

Предметні географічні компетенції - це окремі стосовно ключових і міжпредметних компетенції, що можуть бути конкретно описані і мають формуватися на уроках географії. До предметних географічних компетенцій належать: специфічні для географії знання, вміння й навички та досвід їх застосування; досвід творчої діяльності; вміння мислити просторово й комплексно; емоційно-цінністні установки стосовно довкілля та діяльності в ньому (погляди, переконання, ціннісні орієнтації). Системна робота вчителя, спрямована на формування міжпредметних і предметних компетенцій, сприяє всебічному розвитку особистості учня, його вихованню та соціалізації.

На відміну від компетенції компетентність означає володіння учнем предметною компетенцією, яка грунтується на особистісному ставленні до неї. Отже, компетентність - це сукупність знань, умінь, навичок, досвіду творчої діяльності, емоційно-ціннісних установок і здібностей учня, сформованих на основі його досвіду; результат досягнення (або недосягнення) освітньої норми. Поняття компетентності передбачає сукупність інтелектуальних і фізичних якостей особистості, необхідних для самостійного та ефективного виходу 3 різних життєвих ситуацій, здатність приймати рішення й нести відповідальність за їх реалізацію в різних галузях людської діяльності.

Емпіричні й теоретичні географічні знання засвоюються через різні шляхи пізнання, у мисленнєвому процесі уявлення й поняття взаємопов'язані і становлять єдине ціле. Емпіричні знання відіграють роль підгрунтя, на якому будується система теоретичних знань. На рівні емпіричних знань відбувається аналіз і систематизація фактів,їх узагальнення, формування уявлень про просторове розміщених географічних об'єктів.

До складу емпіричних знань входять: факти, географічна номенклатура та уявлення.

Необхідно зазначити, що фактичний матеріал стає цінним тоді, коли він логічно систематизований і підпорядкований провідним поняттям і теоріям, що дозволить цілеспрямовано від теми до теми, від курсу до курсу розкривати тенденції наукового пізнання.

У шкільних умовах формування наукового пізнання географії особливої уваги 
потребує розкриття географічних зв'язків: просторових, причино-наслідкових між компонентами природи, природно-територіальними комплексами, природою i господарською діяльністю людини.

Географічний понятійний апарат становить основу, на якій грунтується наукове світобачення й мислення учнів основної школи, що сприяє активному формуванню на цьому грунті країнознавчої компетенції. Закладається цей апарат у процесі формування теоретичних знань учнів.

Зазначимо, що поняття визначається як: 1) форма логічного мислення, що відображає головну сутність і зв'язки географічних об'єктів, процесів чи явищ; 2) системне знання предмета вивчення; 3) сукупність усіх ознак, що дозволяють відокремити один предмет від іншого.

Формування понять становить активну навчальну діяльність, яка спрямована на розв'язання пізнавальних завдань. Учнів необхідно навчати прийомам розумової діяльності, тобто формувати логічне мислення і навчати виконувати мисленнєві задачі. Значну частину процесу формування понять складає створення уявлень, які слугують основою понять. Отже, у процесі формування понять необхідно спиратися на образний, просторовий та кількісний матеріал [2].

Розуміння причино-наслідкових зв'язків у довкіллі сприяє формуванню географічної культури учнів основної школи і їхньому інтелектуальному розвитку. Варто зазначити, що засвоєння таких зв'язків учнями вимагає від учителя особливої уваги й зусиль. Учні не можуть завчити взаємолежність причин і наслідків, вони мають їх зрозуміти й усвідомити у процесі засвоєння країнознавчого навчального матеріалу.

Важливою ланкою теоретичних знань є закономірність, що становить об'єктивний постійний взаємозв'язок між об'єктами, процесами чи явищами, зумовлений їх сутністю.

На основі географічних знань формуються вміння й навички учнів. Уміння складається із знання теоретичного матеріалу як змістової основи дії (правила, закону, теорії); знання способів виконання дії, їх змісту і послідовності; призначення необхідного обладнання (приладів, інструментів) і навичок поводження 3 ними; досвіду виконання подібних дій тощо. Програма шкільної географії визначає зміст умінь і навичок, якими мають оволодіти учні. Зокрема, вивчаючи географію у 6 класі, учні оволодівають вміннями працювати 3 картою, аналізувати i структурувати отриманий матеріал, робити висновки, започатковуючи формування картознавчої компетенції [1], необхідної в подальшому.

Культурологічна компетенція демонструє знання про культуру країни, мову, якою в ній говорять, знання особливостей побуту, традицій та звичаїв країни:

- джерел національно-культурної й соціально-ієрархічної інформації;

- етнокультурознавчих і соціолінгвістичних компонентів національної/інших культур;

- соціокультурних стереотипів мовленнєвої поведінки; розпізнавати національно-марковані мовні одиниці;

- декодування соціокультурного змісту навчального тексту; коментувати соціокультурний зміст аналізованих реалій.

До фонових країнознавчих знань відносяться пов'язані з відомостями культурного, матеріально-історичного, географічного характеру уявлення про побут, традиції, звичаї. Фонова інформація відбиває соціально-детермінований досвід носіїв мови і культури.

\section{Тематична рубрика: Населення.}

Категорійно-поняттсвий апарат: населення, природний рух населення, механічний рух населення, національні меншини, основні групи населення, урбанізація, демографія.

Розгляд рубрики передбачено за навчальним виданням: О. Надтока, О. Топузов. Географія : підручник для 9-го класу загальноосвітніх навчальних закладів. - К. : Світ 176

Педагогіка вищої та середної школи. - 2014. - Вип. 41 
знань, 2009. - С. 34-57 Населення Украӥни.Опрацювання матеріалу здійснюється на основі аналізу секторної та стовпчикової діаграм національного складу населення України (с. 48). розроблені за даними таких джерел: Нэгл Г. География в диаграммах / Гаррет Нэгл, Крис Спенсер; пер. с англ. Э. Абушаевой, В. Колесова. - М. : ООО «Издательство Астрель», 2004. - 176 с.; Bradshaw Michael. World Regional Geography : The New Global Order / M. Bradshaw. - Boston, USA : McGraw-Hill Higher Education, 2000. - 622 p.; http://rocich.ru/

Країнознавче спрямування. На рисунку відтворено загальну тенденцію динаміки чисельності населення світу і демографічні процеси, а також особливості показників народжуваності, смертності та природного приросту для окремих регіонів.

Завдання країнознавчого спрямування «Населення та політична карта»: Обгрунтуйте необхідність переходу держав світу від другого до першого типів відтворення населення. Наведіть приклади.

Довідка: Демографічний перехід- це особливість демографічного стану суспільства до економічного розвитку і соціального прогресу. Це поняття $є$ ключовим у поясненні закономірностей відтворення населення в різних типах країн і світі загалом на уроках економічної і соціальної географії. Незважаючи на неможливість 3 великою точністю визначити шляхи майбутньої стабілізації чисельності населення Землі, фази демографічного переходу надають реальну характеристику населення в регіонах i окремих країнах. Знання особливостей показників народжуваності, смертності, природного приросту в історичному розрізі, спосіб життя і дії нинішніх поколінь можуть стати основою для визначення майбутнього демографічного портрету нашої планети на сучасному етапі розвитку суспільства.

Формування країнознавчого складника географічної компетентності учнів основної школи передбачає вивчення країнознавчого і географічного образів країни у нашому випадку - України. Міра кореляції навчального країнознавчого матеріалу із географічним дозволяє визначити такі тематичні рубрики: 1. Держава і країна. 2. Політична карта світу. Типи країн. 3. Міжнародні організації. 4. Просторовотериторіальна організація держав світу. Територія держави. 5. Просторовотериторіальна організація держав світу. Кордони держави та їх функції. 6. Регіональний поділ світу. 7. Національний та етнічний склад населення. 8. Трудові ресурси i зайнятість населення. 9. Типи відтворення населення. Демографічна політика. 10. Природні умови і ресурси. 11. Господарство. Економічний потенціал країни. 12. Господарство. Промисловість. 13. Господарство. Сільське господарство. 14. Господарство. Транспорт. 15. Господарство. Соціальна сфера. Освіта. 16. Господарство. Соціальна сфера. Наука. 17. Світове господарство. Міжнародний поділ праці. 18. Зовнішні економічні зв'язки країни. 19. Культура та духовний розвиток. 20. Рекреаційна політика. Туризм. 21. Екологічна політика. 22. Глобальні проблеми людства.

Відповідно до принципів послідовності й наступності вивчення образів у тісному взаємозв'язку дозволить у старшій школі формування країнознавчоїкомпетентності під час вивчення економічної і соціальної географії:

\section{Типи відтворення населення. Демографічна політика.}

Розкрийте значення поняття демографічна політика.

Назвіть найбільші міста Туреччини (користуючись картою). Охарактеризуйте їх функції.

Назвіть культурно-оздоровчі центри України.

Охарактеризуйте національний склад населення Індії, сутність демографічної політики в Індії.

Поясніть, чому Канада належить до найменш заселених країн світу.

Культура та духовний розвиток.

Педагогіка вищої та середної школи. - 2014. - Вип. 41 
До історико-культурної спадщини Туреччини належать: 1) Трипільська культура; 2) Парфенон; 3) руїни Трої.

Серед віруючих у Франції переважають: 1) протестанти; 2) римо-католики; 3) православні; 4) буддисти.

Коротко схарактеризуйте Трипільську культуру.

Охарактеризуйте історико-культурну спадщину Японії.

Розроблення країнознавчого складника у змісті географічної компетентності учнів основної школи у процесі вивчення географії України уможливлює: формування системи географічних i країнознавчих знань у їх взаємозв'язках; розмежування географічного і країнознавчого образів; реалізацію принципів послідовності й наступності. Вивчення образів у тісному взаємозв'язку сприяє у старшій школі формуванню країнознавчої компетентності під час вивчення економічної і соціальної географії.

Перспективою подальших досліджень визначаємо з'ясування змісту і структури інформаційного (категорійно-поняттєвого) складника географічної компетентності учнів основної школи у процесі вивчення географії України.

1. Скавронський П. Зміст i структура поняття «картознавча компетенція» /Павло Скавронський // Географія та основи економіки в школі. - 2009. № 6. - С. 32-37. 2. Яценко В. Формування й оцінювання ключових компетентностей учня на заняттях географії / В. Яценко // Післядипломна освіта в Україні. - 2007. № 2. - C. 79-82.

УДК 373.5.016:811.161.2

Любов Цоуфал

\section{КОМУНІКАТИВНА КОМПЕТЕНЦІЯ УЧНІВ У КОНТЕКСТІ СУЧАСНИХ ПРОБЛЕМ НАВЧАННЯ УКРАЇНСЬКОЇ МОВИ}

Цоуфал Л. С. Комунікативна компетенція учнів у контексті сучасних проблем навчання української мови.

У статті розкрито сутність поняття «комунікативна компетенція», розглянуто структуру і схарактеризовано основні складники означеного поняття, визначено педагогічні умови формування комунікативної компетенції учнів у процесі навчання української мови.

Ключові слова: комунікативна компетенція, структура комунікативної компетенції, мовленнєвий розвиток учнів, навчання української мови.

Цоуфал Л. С. Коммуникативная компетенция учащихся в контексте современных проблем обучения украинскому языку.

В статье раскрыта суть понятия «коммуникативная компетенция», рассмотрена структура и охарактеризованы основные составляющие названого понятия, выделены педагогические условия формирования коммуникативной компетенции учащихся в процессе обучения украинскому языку.

Ключевые слова: коммуникативная компетенция, структура коммуникативной компетенции, речевое развитие учащихся, обучение украинскому языку.

Tsoufal L. S. Communicative competence of students in the context of contemporary issues of teaching Ukrainian.

The article deals with the definition «communicative competence», examines the structure and characterizes basic components of the forementioned concept, highlights pedagogical conditions of communicative competence formation in the process of Ukrainian language learning.

Key words: communicative competence, structure of communicative competence, students' language development, Ukrainian language teaching. 